\title{
Genetic Composition of Phytophthora infestans in Canada Reveals Migration and Increased Diversity
}

Melanie L. Kalischuk, Agriculture and Agri-Food Canada, Lethbridge, AB Canada; Khalil I. Al-Mughrabi, NB Department of Agriculture and Aquaculture, Wicklow, NB Canada; Rick D. Peters, Agriculture and Agri-Food Canada, Charlottetown, PE Canada; Ron J. Howard, Crop Diversification Centre, Agriculture and Rural Development, Brooks, AB, Canada; H. W. (Bud) Platt, Agriculture and Agri-Food Canada, Charlottetown, PE Canada; and Lawrence M. Kawchuk, Agriculture and Agri-Food Canada, Lethbridge, AB Canada

\begin{abstract}
Kalischuk, M. L., Al-Mughrabi, K. I., Peters, R. D., Howard, R. J., Platt, H. W., and Kawchuk, L. M. 2012. Genetic composition of Phytophthora infestans in Canada reveals migration and increased diversity. Plant Dis. 96:1729-1735.

A dramatic increase in the incidence of late blight and changes within populations of Phytophthora infestans have been observed in various regions of Canada. In this study, the occurrence of several new genotypes of the pathogen was documented with associated phenotypes that dominated pathogen populations. Genotype US-23, previously detected only among isolates from the United States, dominated in the western Canadian provinces of British Columbia, Alberta (AB), Saskatchewan, and Manitoba (MB). Although isolates of US-23 infect both potato and tomato, these isolates were the only genotype recovered from commercial garden centers in Canada. Isolates of genotype US-8, previously dominant throughout Canada, represented the only genotype detected from the eastern Canadian provinces of New Brunswick and Prince Edward Island. Isolates of other genotypes detected in Canada included US-11 in AB, US-24 in MB, and US-22 in Ontario (ON). An additional genotype was detected in $\mathrm{ON}$ which appears to be a deriva-

tive of US-22 that may have arisen through sexual reproduction. However, evidence of clonal reproduction dominated among the isolates collected, and opportunities for sexual reproduction were probably limited because of a surprising geographic separation of the A1 and A2 mating types in Canada. Sensitivity of the US-22, US-23, and US-24 isolates to the fungicide metalaxyl, movement of potato seed and transplants, and weather conditions may have contributed to reduced opportunities for contact between the mating types in fields in Canada. All $P$. infestans isolates were readily distinguished from other related oomycetes with RG57 restriction fragment length polymorphism analysis. Long-distance movement in seed tubers and garden center transplants may have contributed to the rapid spread of the $P$. infestans genotypes across Canada. Tracking pathogen movement and population composition should improve the ability to predict the genotypes expected each year in different regions of Canada.
\end{abstract}

Late blight, caused by the oomycete Phytophthora infestans (Mont.) de Bary, can be a devastating disease of potato and has been increasing in incidence and complexity (14,25,30,35). Crop losses due to this disease occur in all major potato-producing regions in Canada and are caused by pathogen strains with different properties, including aggressiveness on potato and sensitivity to fungicides such as metalaxyl (44-50). Strains with resistance to this systemic fungicide were responsible for significant potato yield losses in the mid- to late 1990s, when late blight reached epidemic proportions throughout North America, initially establishing in eastern regions and later spreading to western areas $(6,7,10,18,29)$. The genome of $P$. infestans was recently sequenced, and the genetic complexity revealed appears to contribute to the destructive capacity of the pathogen such that the economic cost of late blight worldwide is conservatively estimated at more than $\$ 6.7$ billion (31).

Previous increased severity of potato late blight in the United States and Canada coincided with major genetic changes in populations of $P$. infestans (8). Allozyme and DNA analyses con-

Corresponding author: L. M. Kawchuk, E-mail: kawchuk@agr.gc.ca

Accepted for publication 3 June 2012.

http://dx.doi.org/10.1094/PDIS-10-11-0859-RE

This article is in the public domain and not copyrightable. It may be freely reprinted with customary crediting of the source. The American Phytopathological Society, 2012. firmed that most losses during the 1990 s were caused by a new genotype, US- $8(18,19,27)$. Isolates of this genotype were resistant to the fungicide metalaxyl (29), belonged to the A2 mating type, and were very aggressive $(28,34,37,38)$, which contributed to development of epidemics (18). Prior to the mid-1990s, genotypes of the pathogen in the United States and Canada were of the A1 mating type (US-1) and less aggressive on predominant potato cultivars grown commercially. Dominant genotypes that became prevalent in the late 1990 s, such as US-8, were highly pathogenic on tomato in addition to potato, probably providing the competitive advantage of an alternative host $(27,28,37,38)$. The rapid spread of A2 US-8 isolates and the persistence of the A1 US-1 genotype in some regions resulted in a wide distribution of both mating types $(7,27)$. However, both mating types were found together in a small number of sites in Canada and the United States, limiting opportunities for sexual reproduction $(4,7,27)$. Coexistence of both mating types was considered too recent and infrequent for the progeny of sexual reproduction to be detected. However, recent reports of new genotypes indicate that changes may be occurring, which have contributed to the distribution of progeny from sexual reproduction $(30,35)$.

The objectives of this study were to (i) analyze the populations of $P$. infestans in Canada, (ii) test the hypothesis that new genotypes caused the devastating losses to late blight recorded in potato crops in Canada during 2009 and 2010, (iii) determine whether additional migrations in North America or globally have occurred since the last survey for $P$. infestans in Canada, and (iv) search for isolates of $P$. infestans with recombinant genotypes to determine whether sexual recombination is occurring more frequently in Can- 
ada than previously documented. These results advance our understanding of $P$. infestans epidemiology and provide evidence that genotype frequency, distribution, and phenotype may be used to predict the genetic composition and incidence of future $P$. infestans populations.

\section{Materials and Methods}

Isolate preparation. Isolates $(n=103)$ of $P$. infestans from across Canada were obtained from symptomatic potato or tomato plants, potato tubers, and tomato fruit collected from potato and tomato crops, garden centers, commercial greenhouses, and backyard gardens during 2009 to 2010 (Table 1). Tissue that was not sporulating was placed in a petri dish with a small amount of moistened filter paper and incubated at $18^{\circ} \mathrm{C}$ for 1 to 4 days to induce sufficient sporulation for isolation. Individual sporangia were isolated with the aid of a dissecting microscope, transferred to petri plates of rye seed agar (RSA) (2) or V-8 juice agar (42), and incubated at $18^{\circ} \mathrm{C}$. For tissue that was beginning to decay, P. infestans was isolated by placing a fresh tuber slice ('Shepody' potato, approximately $0.75 \mathrm{~cm}$ thick) on top of the infected tissue in a $9-\mathrm{cm}-$ diameter petri dish. A healthy, untreated potato tuber was placed in a beaker containing $10 \% \mathrm{NaOCl}$ and shaken on an orbital shaker for $10 \mathrm{~min}$. The surface-sterilized tuber was then rinsed several times with sterile deionized water in order to remove any traces of $\mathrm{NaOCl}$. A 70-mm filter paper (Whatman number 2; VWR) was placed in an empty, sterile petri dish and lightly moistened with sterile, deionized water. The surface-sterilized potato tuber was cut aseptically into 5- to 8-mm-thick slices and placed on the moistened filter paper in a petri dish. Tissues infected with $P$. infestans were dipped in cold, sterile distilled water and shaken gently. Aliquots of the spore suspension were checked microscopically to confirm the presence of sporangia, and a few drops of each $P$. infestans spore suspension was dispensed on potato tuber slices in a petri dish and incubated at room temperature for 4 to 5 days. White mycelium observed growing on the tuber slices was then checked for sporangia typical of $P$. infestans. Small, colonized RSA squares, each approximately $1 \mathrm{~mm}$ in diameter, were picked from each plate using a sterile needle and then gently deposited on the mycelium on the surface of the tuber slice. The agar square was then placed onto a plate of RSA and incubated at room temperature for 5 to 7 days.

Isolate characterization. Metalaxyl (Ridomil Gold; Syngenta Crop Protection) sensitivity of each isolate of $P$. infestans was determined in a replicated amended-agar assay and the experiment was done at least twice $(29,40)$. Isolates were grown on media containing metalaxyl at 0 or $5 \mu \mathrm{g} / \mathrm{ml}$ and the colony diameter of each plate was measured after 7 days. Treatment differences were examined using a $t$ test. Isolates that produced more than $40 \%$ of the growth, relative to the same isolate on metalaxyl-free media, were labeled resistant to metalaxyl and those that yielded less were considered sensitive.
Mating type of each isolate of $P$. infestans was determined by pairing unknown isolates with a characterized isolate of each of A1 and A2 (P183A and P185A, respectively; provided by K. L. Deahl, United States Department of Agriculture, Beltsville, MD) on RSA. Plates were incubated at $18^{\circ} \mathrm{C}$ in the dark for 2 weeks and oospore formation for each isolate was examined microscopically. Isolates that produced oospores with the known A1 isolate but not with the known A2 isolate were labeled as A2 mating type, and isolates that produced oospores with the known A2 isolate but not with the known A1 isolate were considered to be A1 mating type. Isolate cultures used for allozyme and DNA restriction fragment length polymorphism (RFLP) analyses were grown as described previously $(20,24)$. In summary, genetic analyses were performed on 103 isolates, each derived from a single sporangium initially plated onto RSA. Analyses were replicated at least twice on three or more isolates representing each genotype from each province, to ensure reproducibility. Isolates of $P$. erythroseptica, $P$. brassicae, $P$. nicotianae, and Pythium ultimum were examined as negative control treatments. Each isolate was grown in $20 \mathrm{ml}$ of $\mathrm{V} 8$ broth in $9-\mathrm{cm}-$ diameter, disposable petri dishes incubated at $15^{\circ} \mathrm{C}$ in the dark (22). Each petri dish was inoculated with several small mycelial plugs of the appropriate isolate cut from the border of an actively growing colony, and incubated for 1 to 3 weeks without shaking. Mycelia from two to three broth cultures of each isolate were placed on a 9-cm-diameter Whatman number 1 filter paper disc in a Buchner funnel, and the broth was removed by vacuum filtration. Isolates were examined at the glucose-6-phosphate isomerase (Gpi) locus by cellulose-acetate electrophoresis (CAE) to determine allozyme genotypes $(24,43)$. Reference isolates included US6 (100/100), US-8 (100/111/122), and US-11 (100/100/111) on each CAE plate (25). Migration distances of proteins from uncharacterized isolates were compared with migration distances of proteins from the reference genotypes.

Procedures for DNA RFLP analyses were as described previously (22). Pathogen DNA extractions were each prepared from mycelium ground in liquid nitrogen with a mortar and pestle, suspended in $4 \mathrm{ml}$ of prewarmed $\left(65^{\circ} \mathrm{C}\right)$ extraction buffer $(50$ $\mathrm{mM}$ Tris, $\mathrm{pH} 8.0 ; 150 \mathrm{mM}$ EDTA; and $1 \%$ sarkosyl) by vortexing for 30 to $60 \mathrm{~s}$, and incubated for $20 \mathrm{~min}$ at $65^{\circ} \mathrm{C}$. Subsequently, 4 $\mathrm{ml}$ of cold $5 \mathrm{M} \mathrm{NH}_{4} \mathrm{OAc}$ was added to each tube, mixed by inversion, placed on ice for $20 \mathrm{~min}$, and centrifuged for $10 \mathrm{~min}$ at $10,000 \times g$. The supernatant was transferred to a fresh tube, precipitated with a two-thirds volume (about $5 \mathrm{ml}$ ) of isopropanol, and centrifuged for $5 \mathrm{~min}$ at $10,000 \times \mathrm{g}$. The pellet was dried and resuspended in $0.5 \mathrm{ml}$ of Tris-EDTA (TE; $10 \mathrm{mM}$ Tris [pH 8.0] and $1 \mathrm{mM}$ EDTA). RNAse A was added to a final concentration of $0.1 \mathrm{mg} / \mathrm{ml}$, each tube was incubated for $20 \mathrm{~min}$ at $37^{\circ} \mathrm{C}$, and the contents were then extracted twice with 25:24:1 phenol/ chloroform/isoamyl alcohol. DNA was precipitated with a 1-10th volume of $3 \mathrm{M} \mathrm{NaOAc}$ and two volumes of absolute ethanol. Tubes were centrifuged for $2 \mathrm{~min}$ to collect the DNA. The pellets

Table 1. Genotypes and characteristics of Phytophthora infestans isolates collected in Canada from 2009 to 2010

\begin{tabular}{|c|c|c|c|c|c|c|c|}
\hline Province & Host & Genotype & Mating type & Allozyme $^{\mathrm{a}}$ & RG57 RFLPb & Metalaxyl-me & Isolates \\
\hline British Columbia & Potato & US-23 & A1 & $100 / 100$ & 11001100010011001001100111 & $\mathrm{~S}$ & 9 \\
\hline \multirow[t]{3}{*}{ Alberta } & Potato & US-11 & A1 & 100/100/111 & 10101110010011010101100101 & $\mathrm{R}$ & 8 \\
\hline & Potato & US-23 & A1 & $100 / 100$ & 11001100010011001001100111 & $\mathrm{~S}$ & 3 \\
\hline & Tomato & US-23 & A1 & $100 / 100$ & 11001100010011001001100111 & $\mathrm{~S}$ & 7 \\
\hline \multirow[t]{2}{*}{ Saskatchewan } & Tomato & US-23 & $\mathrm{A} 1$ & $100 / 100$ & 11001100010011001001100111 & $\mathrm{~S}$ & 5 \\
\hline & Potato & US-23 & A1 & $100 / 100$ & 11001100010011001001100111 & $\mathrm{~S}$ & 7 \\
\hline \multirow[t]{3}{*}{ Manitoba } & Tomato & US-23 & A1 & $100 / 100$ & 11001100010011001001100111 & $\mathrm{~S}$ & 3 \\
\hline & Potato & US-23 & $\mathrm{A} 1$ & $100 / 100$ & 11001100010011001001100111 & $\mathrm{~S}$ & 16 \\
\hline & Potato & US-24 & $\mathrm{A} 1$ & $100 / 100 / 111$ & 10101010010011010011101101 & $\mathrm{~S}$ & 16 \\
\hline \multirow[t]{2}{*}{ Ontario } & Tomato & US-22 & $\mathrm{A} 2$ & $100 / 122$ & 10001000000011010001100101 & $\mathrm{~S}$ & 3 \\
\hline & Tomato & US-22a & A2 & $100 / 122$ & 10001000000011010101100101 & $\mathrm{~S}$ & 2 \\
\hline New Brunswick & Potato & US-8 & $\mathrm{A} 2$ & $100 / 111 / 122$ & 10001000010011010001101101 & $\mathrm{R}$ & 7 \\
\hline Prince Edward Island & Potato & US- 8 & A2 & $100 / 111 / 122$ & 10001000010011010001101101 & $\mathrm{R}$ & 17 \\
\hline
\end{tabular}

${ }^{a}$ Glucose-6-phosphate isomerize locus detected by cellulose-acetate electrophoresis $(29,40)$.

${ }^{\mathrm{b}}$ Restriction fragment length polymorphic (RFLP) pattern produced with EcoRI and RG57 (20,24).

${ }^{c} \mathrm{~S}=$ sensitive and $\mathrm{R}=$ resistant to metalaxyl, tested as detailed in the main text. 
were then dried, washed in $70 \%$ ethanol, and resuspended in 100 $\mu \mathrm{l}$ of TE.

The multilocus, Phytophthora infestans-specific RFLP probe, RG57, was used to characterize isolates as previously described (22). A 1.2-kb DNA product was amplified from P. infestans US11 genomic DNA using the synthetic oligonucleotide primers RG57P1F (5'ACCATGCAGCTGAATTGCCAT3') and RG57P1R $\left(5^{\prime}\right.$ CTCTCATAACCGACGTTTTC $\left.3^{\prime}\right)$ that are specific for the RG57 sequence (GenBank accession AF495861). A polymerase chain reaction (PCR) assay was performed in a $100-\mu$ l volume of $10 \mathrm{mM}$ Tris- $\mathrm{HCl}$ ( $\mathrm{pH} \mathrm{8.3),} 50 \mathrm{mM} \mathrm{KCl}, 1.5 \mathrm{mM} \mathrm{MgCl} 2,0.001 \%$ gelatin, $0.25 \mathrm{mM}$ each dNTP, $2 \mu \mathrm{M}$ each primer, $1.0 \mathrm{U}$ of Taq DNA polymerase (Perkin Elmer Cetus), $0.5 \mathrm{U}$ of Vent Taq DNA polymerase (New England Biolabs, Inc.), and $200 \mathrm{ng}$ of template DNA, as previously described (13). Amplified DNA was ligated into pBlueScript SK+ (Stratagene) and Escherichia coli cells were transformed. The double-stranded DNA sequence of each isolate was determined with a BigDye Terminator Cycle Sequencing Kit and an ABI 377 automated sequencer (Applied Biosystems) using primers derived from the genomic sequence and the polylinker cloning site of the vector.

\section{Results}

Pathogen collection. All isolates were recovered from diseased potato or tomato tissues, including leaves, stems, and tubers. In all, 103 isolates of $P$. infestans were collected from potato and tomato plants, seed, or fruit in 2009 through 2010 (Table 1). Isolates found on potato plants infected leaves and tubers, whereas those on tomato infected the stem, leaves, and the fruit (Fig. 1). Isolates of both mating types were found on potato and tomato samples. Only isolates of mating type A1 were obtained from the British Columbia (BC), Alberta (AB), Saskatchewan (SK), and Manitoba (MB) samples, whereas all isolates from Ontario (ON), New Brunswick (NB), and Prince Edward Island (PE) were the A2 mating type (Table 1). Three genotypes were detected based on Gpi allozyme analysis and mating type, including Gpi 100/100 A1 (isolates of
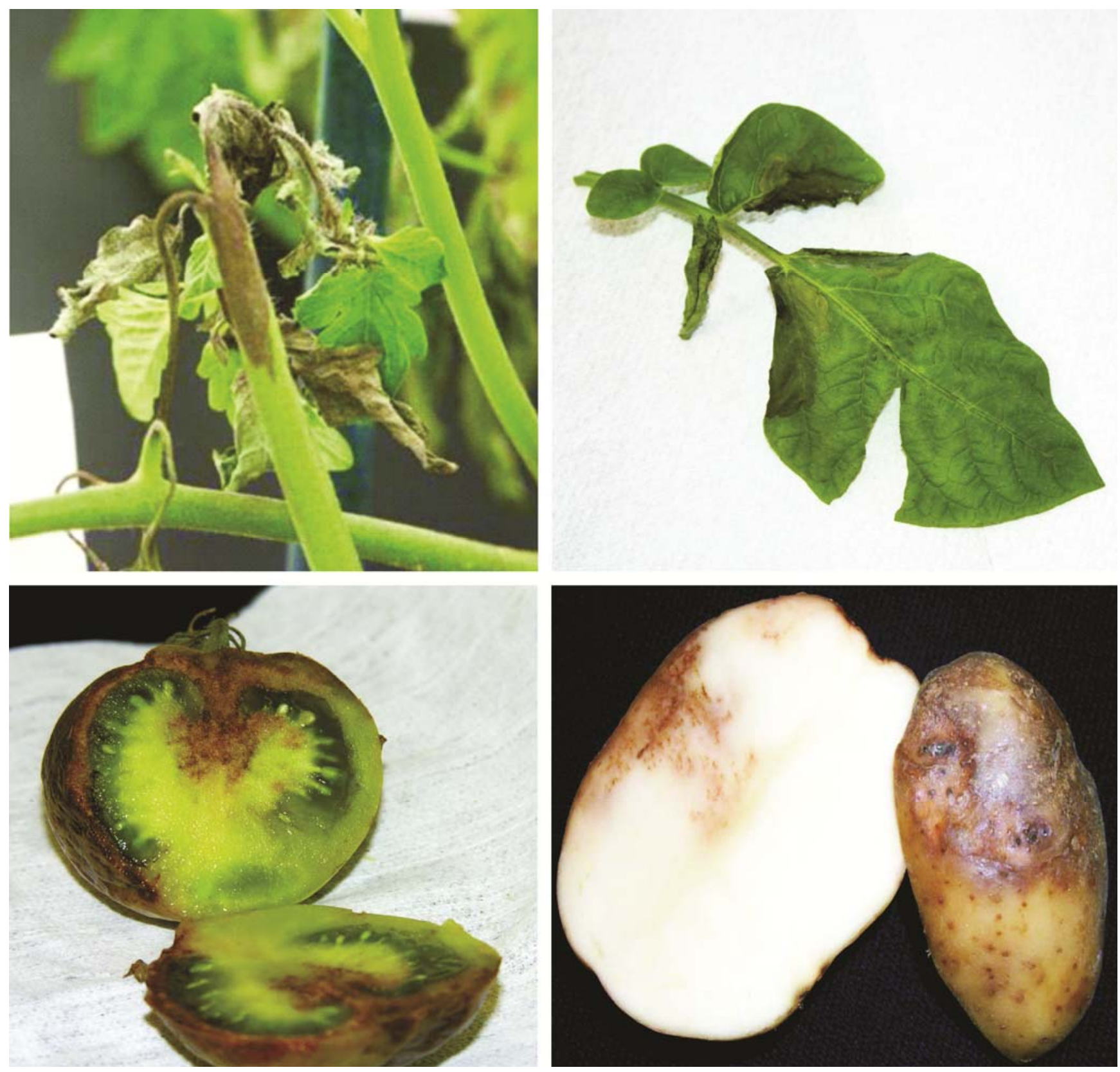

Fig. 1. Symptom development associated with infection of potato and tomato samples by Phytophthora infestans isolates collected in Canada between 2009 and 2010 . All tomato isolates of $P$. infestans ( $n=23$ ) were genotype US-22, US-22a, or US-23 and produced stem necrosis (top left) and diseased fruit (lower left), and infected adjacent tomato plants. All potato isolates ( $n=80$ ) were US-8, US-11, US-23, and US-24 genotypes and were typically isolated from infected leaves (top right) and tubers (lower right). Only isolates of US-23 were recovered from both tomato and potato samples. 
US-6 and US-23), Gpi 100/1111/122 A2 (isolates of US-8), and Gpi 100/100/111 A1 (isolates of US-11 and US-24) (Fig. 2). Only the US-8 genotype was isolated from samples collected in eastern Canada (PE and NB). There were no US-8 genotype isolates from the other provinces. Only the US-8 (average $80 \pm 9 \%$ growth of that on nonamended agar) and US-11 (average $78 \pm 18 \%$ growth) isolates were classified as metalaxyl insensitive, and all other genotypes showed metalaxyl sensitivity $(P<0.01)$. The US22, US22a, and US23 isolates showed no growth on medium amended with metalaxyl at $5 \mu \mathrm{g} / \mathrm{ml}$ agar, and growth of US-24 isolates averaged $13 \pm 8 \%$

DNA RFLP analysis. DNA analysis confirmed all the US-8 genotype identifications made by allozyme analyses and mating type. All isolates previously identified as US-6 or US-23 by allozyme analyses were genotype US-23 (Fig. 3). Sixteen isolates from MB were shown to be genotype US-24 (Table 1). Isolates of the US-22 $(n=3)$ genotype were identified from $\mathrm{ON}$ in addition to isolates of a potentially new genotype, US-22a $(n=2)$, with a unique profile that resembled US-22 but with an additional polymorphism (Fig. 4). Hybridization of RG57 under high-stringency conditions to DNA from other $P$. infestans-related pathogens (Pythium ultimum, Phytophthora erythroseptica, P. brassicae, and $P$. nicotianae) was not observed. Only the US-23 genotype was recovered from both tomato and potato samples (Table 1). The US8, US-11, and US-24 genotypes were only recovered from potato

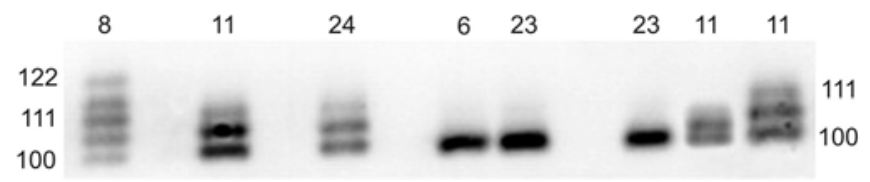

Fig. 2. Allozyme profile of Phytophthora infestans isolates from potato and tomato samples collected in Canada in 2009 to 2010, tested on cellulose-acetate gels stained for glucose-6-phosphate isomerase (Gpi) $(24,25,43)$. The Gpi genotypes shown are indicated at the top of the gel and include US-6, Gpi 100/100 (control isolate); US-8, Gpi 100/111/122; US-11, Gpi 100/100/111; US-23, Gpi 100/100; and US-24, Gpi 100/100/111. The Gpi genotype of US-6 was identical to that of US-23, Gpi 100/100, and US-11 was indistinguishable from US-24, Gpi 100/100/111.

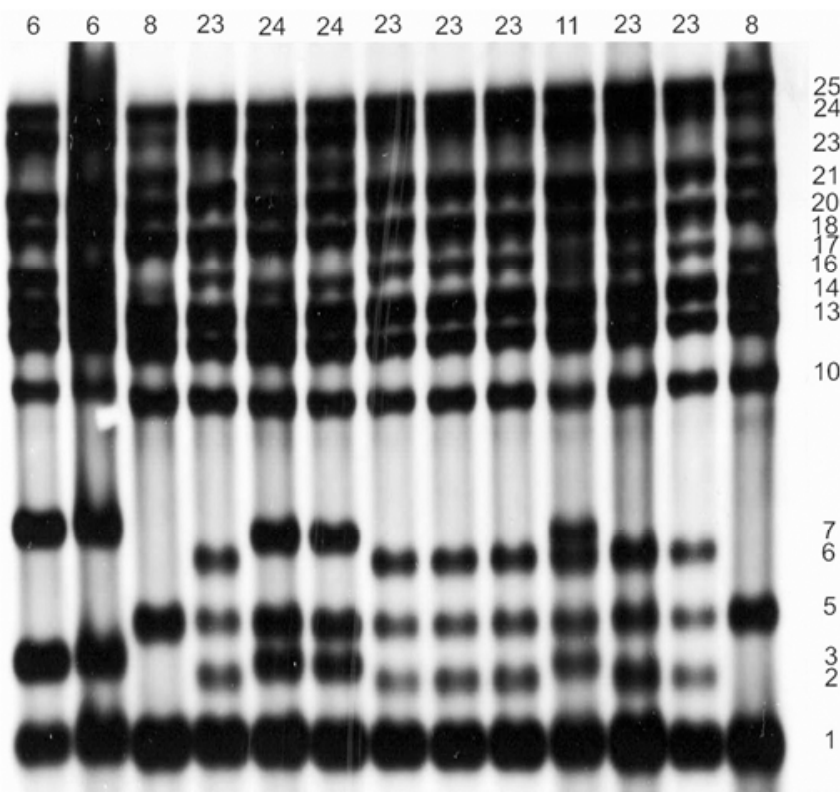

Fig. 3. Restriction fragment length polymorphism profile of dominant Phytophthora infestans genotypes of isolates $(n=76)$ recovered in 2010 from potato and tomato samples collected across Canada $(20,24)$. Genotype designations are indicated above each lane and the RG57 products are shown on the right of the blot. Genotypes US-6 (a standard control isolate) and US-11 were distinguished from US-23 and US-24 isolates by the RG57 profiles. Locations of each genotype were as follows: US-8, New Brunswick and Prince Edward Island; US-11, Alberta; US-23, British Columbia, Alberta, Saskatchewan, and Manitoba; and US-24, Manitoba. samples, and US-22 and US-22a isolates only from tomato samples.

Population composition. In western Canada (BC, AB, SK, and MB), the dominant genotype of $P$. infestans identified was US-23 (Fig. 5; Table 1). Initially isolated from tomato plants at garden retail centers, the genotype was later found on potato samples but symptoms were less severe on potato compared with tomato plants. This represents the first documentation of the dominance of isolates of genotype US-23 in western Canada. In AB, isolates of genotype US-11 were exclusively obtained from potato samples and have been identified previously in Canada (48). Sixteen potato samples from MB were infected with the US-24 genotype that has not been reported previously in Canada. All isolates of US-11, US23, and US-24 genotypes were recovered in western Canada (BC, $\mathrm{AB}, \mathrm{SK}$, and $\mathrm{MB})$. Interestingly, all of the genotypes from western Canada were of the A1 mating type (Table 1).

All diseased potato samples from PE and NB $(n=24)$ had the US-8 genotype of $P$. infestans that has been the dominant genotype in this region of Canada since the mid 1990s $(4,8,20)$. All of these isolates were metalaxyl insensitive and confirmed to be of the A2 mating type. Isolates of $P$. infestans from tomato samples in ON were determined to be genotype US-22, which has not previously been reported in Canada. Surprisingly, a distinct genotype was also isolated from ON tomato samples in 2010, based on a distinctive RFLP pattern that closely resembled that of US22 (Fig. 4). This new genotype was designated as US-22a and, like US-22, the isolates were sensitive to metalaxyl and of the A2 mating type. All isolates from eastern Canada (ON, NB, and PE) were of the A2 mating type, producing a dichotomy in $P$. in-

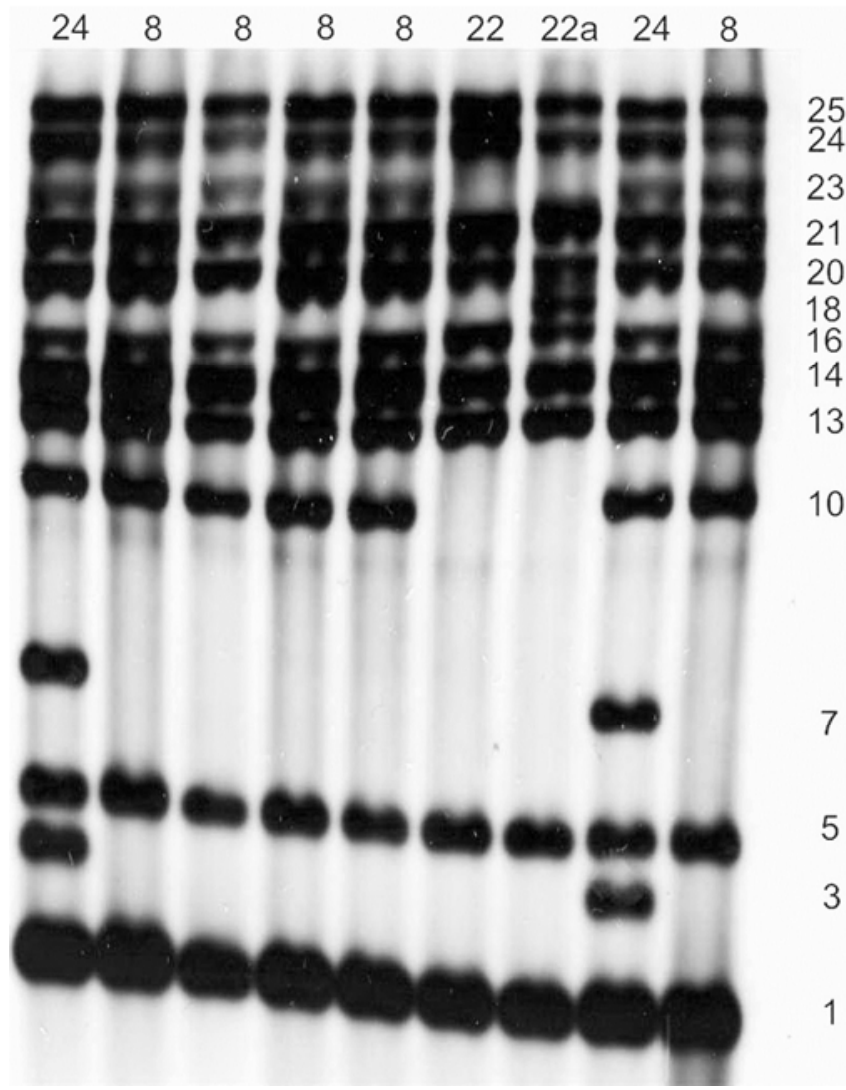

Fig. 4. Restriction fragment length polymorphisms (RFLPs) showing the Phytophthora infestans genotype of isolates from Canada designated as US-22a $(20,24)$. The US-22 (mating type A2) and US-22a genotypes lacked RFLP product 10 and were identified only on samples of infected tomato plants from Ontario, Canada. The abundance of US-23 isolates in Canada may have facilitated a sexual cross with isolates of US-22 to produce the US-22a genotype, although the presence of DNA product 18 in isolates of US-22a suggests that US-11 (mating type A1) may be the other parental isolate. Genotype designations are indicated at the top of the image, and RFLP products are shown on the right. 
festans A1 and A2 mating types in western and eastern Canada, respectively (Fig. 5).

\section{Discussion}

The results of this study suggest that the devastating late blight epidemics on potato and tomato in Canada during 2009 and 2010 were caused primarily by isolates of the US- 8 and US-23 P. infestans genotypes. This was unexpected, based on previous reports and the relatively recent emergence of genotypes such as US-23 in the United States and Canada $(27,35)$. Surprisingly, isolates of $P$. infestans collected in this survey from western Canada were dominated by US-23 (68\%), whereas isolates from the eastern regions were mostly US-8 (83\%). Similar rapid genotype displacement of US-1 isolates by US-8 isolates has been documented in Oregon, Washington, Wisconsin, and Canada $(27,39,41)$. Similar replacement of US-1 isolates was reported in Europe, Asia, and South America but the genotypes causing the displacements were different in each location $(5,11,12,14-16,30,36,51-53)$. Although isolates of several genotypes such as US-22, US-23, and US-24 have made long-distance migrations, the isolates have not been found outside of Canada and the United States; and the genotypes characteristic of the European, South American, and Asian migrations have not been detected within Canada and the United States $(11,19,21)$. Therefore, additional long-distance migrations could spread these destructive genotypes to new locations.

Previous studies showed it was not always possible to predict the genotypes of $P$. infestans that would be present in a region each year $(1,3,27)$. Several factors influence the occurrence of late blight such as pathogen inoculum source and weather, which may contribute to this uncertainty. Conducive weather is critical to the development of late blight, and the recent atypical, cool, moist conditions have provided unusually favorable conditions for late blight in some regions of western North America (Environment Canada, http://www.ec.gc.ca). Retail tomato plants planted in western Canada were shown to be infected with US-23 isolates and these infected tomato plants probably introduced the genotype to this region because there was no evidence for US-23 in this area during previous years (35). Thus, transport of infected plants across the continent has helped distribute inoculum of a genotype that appears to have originated further south $(7,25,35)$. In addition, isolates of US-23 appear to have much greater pathogenic fitness than isolates of US-8 on tomato, which may have played a role in the rapid increase in distribution (35). This emphasizes the importance of planting disease-free seed or plants, including those of alternative hosts. Distribution of $P$. infestans in plant material has been demonstrated previously and genotypes identified in seed and transplants gave a better prediction of predominant genotypes in a subsequent growing season than did identification of genotypes that were present in the crop the previous year $(1,20,27,35)$. Surveillance of potential $P$. infestans sources and the movement in potato seed and tomato plants should improve the ability to predict the occurrence of genotypes in various locations.

Throughout the United States and Canada, there still is limited evidence for sexual recombination of $P$. infestans, even though both mating types have become distributed widely $(7,27)$. This is probably because both mating types have seldom been found in the same field or geographic location. Isolates of both mating types were found in only 1 field in Florida among more than 100 fields from which multiple isolates were obtained (27). Another study found both mating types together only occasionally in Florida and Texas (7). Both mating types were also found together at sites sampled in $\mathrm{BC}$ and $\mathrm{NB}$, along with evidence of sexual recombination $(2,4)$. Because these studies were conducted when the A2 isolate was first documented in the United States and Canada, the opportunities for sexual recombination at that time were minimal $(4,7,27)$. Surprisingly, although several different $P$. infestans genotypes were identified in this study from 2009 through 2010 in western Canada $(\mathrm{BC}, \mathrm{AB}, \mathrm{SK}$, and $\mathrm{MB})$ and eastern Canada $(\mathrm{ON}, \mathrm{NB}$, and $\mathrm{PE})$, the mating types present in these regions were all $\mathrm{A} 1$ or $\mathrm{A} 2$, respectively. This dichotomy in mating types should limit opportunities for sexual reproduction. Although the limited sampling in this study may underestimate the distribution of both mating types, the results indicate that, in Canada, opportunities for sexual recombination of $P$. infestans remain limited.

Our analyses confirmed that metalaxyl sensitivity and genotype of isolates of $P$. infestans remain correlated for US-8, US-11, US22, US-23, and US-24 isolates. Only the US-8 and US-11 isolates were highly resistant to metalaxyl, and the systemic fungicide may contribute to mating type selection (25). Cultural practices, movement of $P$. infestans-infected seed and transplants within and among geographic regions, and environmental conditions have likely preferentially propagated specific pathogen genotypes be-

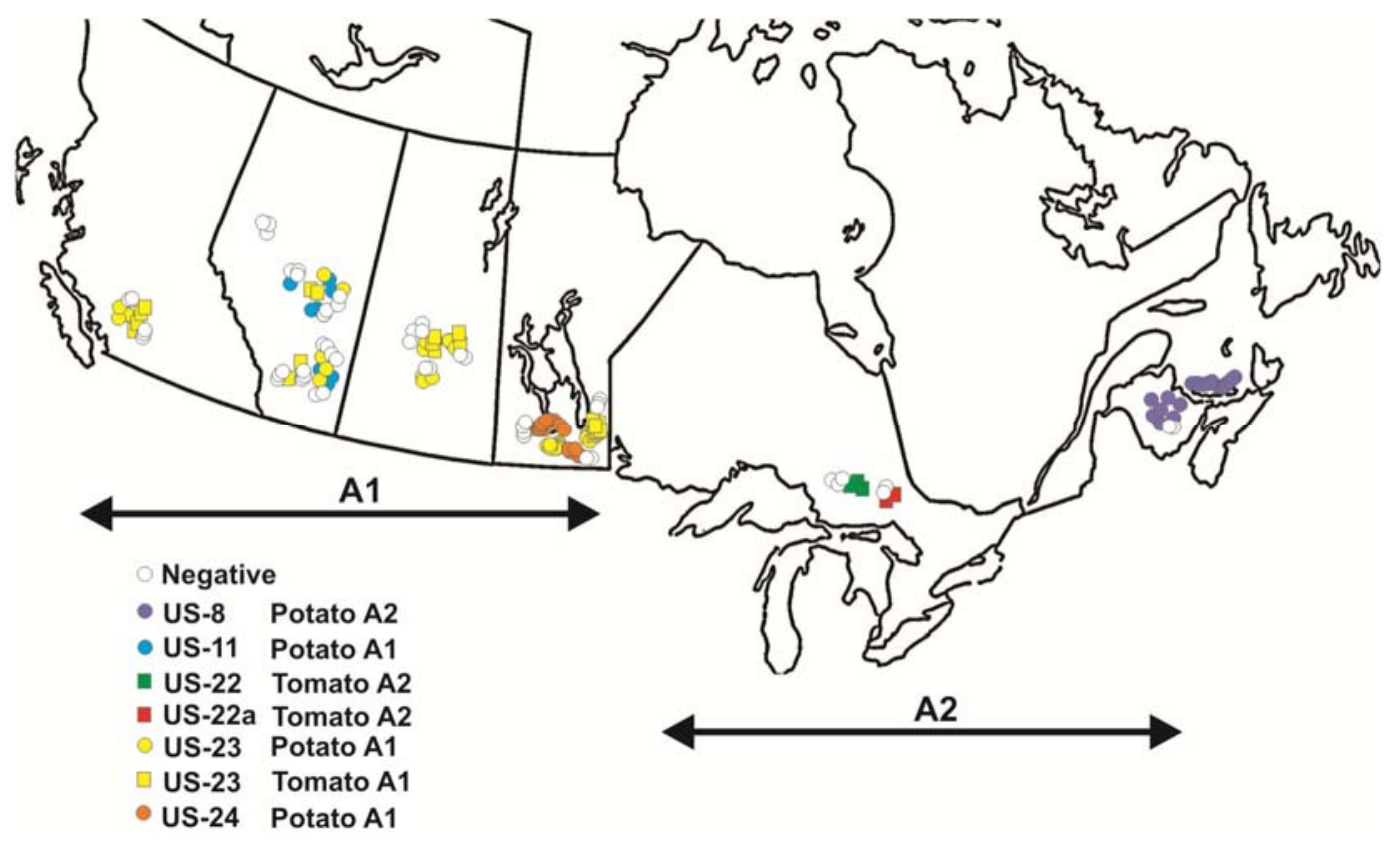

Fig. 5. Locations of Phytophthora infestans populations and mating type distribution in major potato production areas of Canada sampled during 2009 to 2010 from which samples with symptoms of late blight were collected. Potato samples (US-8, $n=24$; US-11, $n=8$; US-23, $n=35$; and US-24, $n=16$ ) are indicated by circles and tomato samples (US-22, $n=3$; US-22a, $n=2$; and US-23, $n=15$ ) are shown as squares. Samples that failed to produce an isolate were labeled negative. Areas identified show general distribution and diversity of genotypes and geographic separation of the A1 and A2 mating types. 
longing to one strain or mating type, as documented for other potato pathogens $(23,26,32,34)$.

A potential recombinant genotype was detected in 2010 from tomato samples in ON. The genotype, which was the A2 mating type, produced an RFLP profile with DNA products $1,5,14,15$, $17,20,21,24$, and 25 , which resembled that of the US-22 genotype found only in ON but with an additional DNA 18 product. This isolate could have originated by sexual recombination between an isolate of US-22 and an isolate of one of the A1 genotypes. The presence of the RFLP DNA band 18 in US-11 isolates suggests that an isolate of US-11 may be the A1 parent; however, the prevalence of the US-23 genotype in Canada would have provided more opportunities for sexual reproduction. Previous reports of recombination between isolates of US-6 and US-8 may have been the origin of the Gpi 100/100/111 genotype of US-11 (25). Four other potential recombinant genotypes were found previously in fields of tomato. US-12 and US-13 isolates were found in New York; US-16 in California; and US-17 in Alabama, Florida, and New York (25). All of these genotypes could have arisen by hybridization between isolates of US-6 and US-8 (25). However, potential recombinant genotypes $(n=2)$ made up only a small proportion (2\%) of the total samples, compared with some sexual populations in Europe in which nearly $100 \%$ of the isolates tested were recombinant $(12,53)$. Future monitoring is required to determine whether sexually reproducing populations of $P$. infestans have become established in Canada and the United States, and how they might affect late blight epidemiology.

The presence of new genotypes of $P$. infestans in different regions of Canada presents a challenge for late blight control, with each strain having distinctive traits, including host preference and fungicide sensitivity. Global movement of seed and transplants provides an unprecedented opportunity for rapid migration of new genotypes into areas with suitable environmental conditions for disease outbreaks. Models for predicting late blight epidemics will need to be evaluated and adjusted to accommodate these new genotypes. The role and effect of inoculum on late blight epidemics is apparently influenced by pathogen migration, climate, and genotype $(9,14-17,25,26,33,35,54)$. As a result, epidemics may occur more often and earlier in the season, and be more difficult to control. Continued monitoring of the pathogen across Canada and the United States should provide early warning of the anticipated genotypes and impending outbreaks of late blight. Integrated methods of disease management will be required to control the new $P$. infestans genotypes.

\section{Acknowledgments}

This project was supported, in part, by the Canadian Horticultural Council and AAFC Projects 1539 and 1751 . We thank A. Lévesque for helpful discussions; the many collaborators throughout Canada who supplied infected tissue or isolates, without whose assistance this study could not have been completed; and J. Lynn and R. Poirier for excellent technical assistance.

\section{Literature Cited}

1. Abbott, C. L., Gilmore, S. R., Lewis, C. T., Chapados, J. T., Peters, R. D., Platt, H. W., Coffey, M. D., and Lévesque, C. A. 2010. Development of a SNP genetic marker system based on variation in microsatellite flanking regions of Phytophthora infestans. Can. J. Plant Pathol. 32:440-457.

2. Caten, C. E., and Jinks, J. L. 1968. Spontaneous variability of single isolates of Phytophthora infestans. I. Cultural variation. Can. J. Bot. 46:329348.

3. Chen, Q., Kawchuk, L. M., Lynch, D. R., Goettel, M. S., and Fujimoto, D. K. 2003. Identification of late blight, Colorado potato beetle, and blackleg resistance in three Mexican and two South American wild 2x (1EBN) Solanum species. Am. J. Potato Res. 80:9-19.

4. Chycoski, C. I., and Punja, Z. K. 1996. Characteristics of populations of Phytophthora infestans from potato in British Columbia and other regions of Canada during 1993 to 1995. Plant Dis. 80:579-589.

5. Day, J. P., and Shattock, R. C. 1997. Aggressiveness and other factors relating to displacement of populations of Phytophthora infestans in England and Wales. Eur. J. Plant Pathol. 103:379-391.

6. Deahl, K. L., DeMuth, S. P., Pelter, G., and Ormrod, D. J. 1993. First report of resistance of Phytophthora infestans to metalaxyl in eastern Washington and southwestern British Columbia. Plant Dis. 77:429.

7. Deahl, K. L., DeMuth, S. P., Sinden, S. L., and Rivera-Peña, A. 1995.
Identification of mating types and metalaxyl resistance in North American populations of Phytophthora infestans. Am. Potato J. 72:35-49.

8. Deahl, K. L., Goth, R. W., Young, R., Sinden, S. L., and Gallegly, M. E. 1991. Occurrence of the A2 mating type of Phytophthora infestans in the United States and Canada. Am. Potato J. 68:717-725.

9. Deahl, K. L., and Inglis, D. A. 1995. Occurrence of metalaxyl-insensitive Phytophthora infestans on Solanum sarrachoides in northwestern Washington. Plant Dis. 79:540.

10. Deahl, K. L., Inglis, D. A., and DeMuth, S. P. 1993. Testing for resistance to metalaxyl in Phytophthora infestans isolates from northwestern Washington. Am. Potato J. 70:779-795.

11. Drenth, A., Goodwin, S. B., Fry, W. E., and Davidse, L. C. 1993. Genotypic diversity of Phytophthora infestans in the Netherlands revealed by DNA polymorphisms. Phytopathology 83:1087-1092.

12. Drenth, A., Tas, I. C. Q., and Govers, F. 1994. DNA fingerprinting uncovers a new sexually reproducing population of Phytophthora infestans in the Netherlands. Eur. J. Plant Pathol. 100:97-107.

13. Entz, S. C., Johnson, D. L., and Kawchuk, L. M. 2005. Development of a PCR-based diagnostic assay for the specific detection of the fungus $M e$ tarrhizium anisopliae var. acridum in grasshoppers. Mycol. Res. 109:13021312.

14. Forbes, G. A., Escobar, X. C., Ayala, C. C., Revelo, J., Ordoñez, M. E., Fry, B. A., Doucett, K., and Fry, W. E. 1997. Population genetic structure of Phytophthora infestans in Ecuador. Phytopathology 87:375-380.

15. Forbes, G. A., Goodwin, S. B., Drenth, A., Oyarzun, P., Ordoñez, M. E., and Fry, W. E. 1998. A global marker database for Phytophthora infestans. Plant Dis. 82:811-818.

16. Fry, W. E., Drenth, A., Spielman, L. J., Mantel, B. C., Davidse, L. C., and Goodwin, S. B. 1991. Population genetic structure of Phytophthora infestans in the Netherlands. Phytopathology 81:1330-1336.

17. Fry, W. E., and Goodwin, S. B. 1995. Recent migrations of Phytophthora infestans. Pages 89-95 in: Phytophthora infestans 150. L. J. Dowley, E. Bannon, L. R. Cooke, T. Keane, and E. O’Sullivan, eds. Boole Press, Ltd., Dublin.

18. Fry, W. E., and Goodwin, S. B. 1997. Resurgence of the Irish potato famine fungus. BioScience 47:363-371

19. Goodwin, S. B. 1997. The population genetics of Phytophthora. Phytopathology 87:462-473.

20. Goodwin, S. B., Cohen, B. A., Deahl, K. L., and Fry, W. E. 1994. Migration from northern Mexico as the probable cause of recent genetic changes in populations of Phytophthora infestans in the United States and Canada. Phytopathology 84:553-558.

21. Goodwin, S. B., Cohen, B. A., and Fry, W. E. 1994. Panglobal distribution of a single clonal lineage of the Irish potato famine fungus. Proc. Natl. Acad. Sci. USA 91:11591-11595.

22. Goodwin, S. B., Drenth, A., and Fry, W. E. 1992. Cloning and genetic analyses of two highly polymorphic, moderately repetitive nuclear DNAs from Phytophthora infestans. Curr. Genet. 22:107-115.

23. Goodwin, S. B., and McGrath, M. T. 1995. Insensitivity to metalaxyl among isolates of Phytophthora erythroseptica causing pink rot of potato in New York. Plant Dis. 79:967.

24. Goodwin, S. B., Schneider, R. E., and Fry, W. E. 1995. Use of cellulose acetate electrophoresis for rapid identification of allozyme genotypes of Phytophthora infestans. Plant Dis. 79:1181-1185.

25. Goodwin, S. B., Smart, C. D., Sandrock, R. W., Deahl, K. L., Punja, Z. K., and Fry, W. E. 1998. Genetic change within populations of Phytophthora infestans in the United States and Canada during 1994 to 1996: role of mitigation and recombination. Phytopathology 88:939-949.

26. Goodwin, S. B., Spielman, L. J., Matuszak, J. M., Bergeron, S. N., and Fry, W. E. 1992. Clonal diversity and genetic differentiation of Phytophthora in festans populations in northern and central Mexico. Phytopathology 82:955 961.

27. Goodwin, S. B., Sujkowski, L. S., Dyer, A. T., Fry, B. A., and Fry, W. E. 1995. Direct detection of gene flow and probable sexual reproduction of Phytophthora infestans in northern North America. Phytopathology 85:473479.

28. Goodwin, S. B., Sujkowski, L. S., and Fry, W. E. 1995. Rapid evolution of pathogenicity within clonal lineages of the potato late blight disease fungus. Phytopathology 85:669-676.

29. Goodwin, S. B., Sujkowski, L. S., and Fry, W. E. 1996. Widespread distribution and probable origin of resistance to metalaxyl in clonal genotypes of Phytophthora infestans in the United States and western Canada. Phytopathology 86:793-800.

30. Guo, L., Zhu, X.-Q., Hu, C.-H., and Ristaino, J. B. 2010. Genetic structure of Phytophthora infestans populations in China indicates multiple migration events. Phytopathology 100:997-1006.

31. Haas, B.J., Kamoun, S., Zody, M. C., Jiang, R. H. Y., Handsaker, R. E., Cano, L. M., Grabherr, M., Kodira, C. D., Raffaele, S., Torto-Alalibo, T., Bozkurt, T.O., Ah-Fong, A. M. V., Alvarado, L., Anderson, V. L., Armstrong, M. R., Avrova, A., Baxter, L., Beynon, J., Boevink, P. C. Bollmann, S. R., Bos, J. I. B., Bulone, V., Cai, G., Cakir, C., Carrington, J. C., Chawner, M., Conti, L., Costanzo, S., Ewan, R., Fahlgren, N., Fischbach, M. A., Fugelstad, J., Gilroy, E. M., Gnerre, S., Green, P. J., Grenville-Briggs, L. J., Griffith, J., Grünwald, N. J., Horn, K., Horner, N. 
R., Hu, C.-H., Huitema, E., Jeong, D.-H., Jones, A. M. E., Jones, J. D. G., Jones, R. W., Karlsson, E. K., Kunjeti, S. G., Lamour, K., Liu, Z., Ma, L., MacLean, D., Chibucos, M. C., McDonald, H., McWalters, J., Meijer, H. J. G., Morgan, W., Morris, P. F., Munro, C. A., O'Neill, K., Ospina-Giraldo, M., Pinzón, A., Pritchard, L., Ramsahoye, B., Ren, Q., Restrepo, S., Roy, S., Sadanandom, A., Savidor, A., Schornack, S., Schwartz, D. C., Schumann, U. D., Schwessinger, B., Seyer, L., Sharpe, T., Silvar, C., Song, J., Studholme, D. J., Sykes, S., Thines, M., van de Vondervoort, P. J. I., Phuntumart, V., Wawra, S., Weide, R., Win, J., Young, C., Zhou, S., Fry, W., Meyers, B. C., van West, P., Ristaino, J., Govers, F., Birch, P. R. J., Whisson, S. C., Judelson, H. S., and Nusbaum, C. 2009. Genome sequence and analysis of the Irish potato famine pathogen Phytophthora infestans. Nature 461:393-398.

32. Holley, J. D., and Kawchuk, L. M. 1996. Distribution of thiabendazole and thiophanate-methyl resistant strains of Helminthosporium solani and Fusarium sambucinum in Alberta potato storages. Can. Plant Dis. Surv. 76:21-27.

33. Johnson, D. A., Cummings, T. F., Hamm, P. B., Rowe, R. C., Miller, J. S., Thornton, R. E., Pelter, G. Q., and Sorensen, E. J. 1997. Potato late blight in the Columbia Basin: an economic analysis of the 1995 epidemic. Plant Dis. 81:103-106.

34. Kato, M., Mizubuti, E. S., Goodwin, S. B., and Fry, W. E. 1997. Sensitivity to protectant fungicides and pathogenic fitness of clonal lineages of Phytophthora infestans in the United States. Phytopathology 87:973-978.

35. Kawchuk, L. M., Howard, R. J., Peters, R. D., and Al-Mughrabi, K. I. 2011. First report of Phytophthora infestans genotype US23 causing late blight in Canada. Plant Dis. 95:873.

36. Koh, Y. J., Goodwin, S. B., Dyer, A. T., Cohen, B. A., Ogoshi, A., Sato, N., and Fry, W. E. 1994. Migrations and displacements of Phytophthora infestans populations in East Asian countries. Phytopathology 84:922-927.

37. Lambert, D. H., and Currier, A. I. 1997. Differences in tuber rot development for North American clones of Phytophthora infestans. Am. Potato J. 74:39-43.

38. Legard, D. E., Lee, T. Y., and Fry, W. E. 1995. Pathogenic specialization in Phytophthora infestans: aggressiveness on tomato. Phytopathology 85:1356-1361.

39. Marshall-Farrar, K. D., McGrath, M., James, R. V., and Stevenson, W. R. 1998. Characterization of Phytophthora infestans in Wisconsin from 1993 to 1995. Plant Dis. 82:434-436.

40. Matuszak, J. M., Fernandez-Elquezabal, J., Gu, W. K., Villarreal-Gonzalez, M., and Fry, W. E. 1994. Sensitivity of Phytophthora infestans populations to metalaxyl in Mexico: distribution and dynamics. Plant Dis. 78:911-916.

41. Miller, J. S., Hamm, P. B., and Johnson, D. A. 1997. Characterization of the
Phytophthora infestans population in the Columbia Basin of Oregon and Washington from 1992 to 1995 . Phytopathology 87:656-660.

42. Miller, P. M. 1955. V-8 juice agar as a general-purpose medium for fungi and bacteria. Phytopathology 45:461-462.

43. Oudemans, P., and Coffey, M. D. 1991. A revised systematics of twelve papillate Phytophthora species based on isozyme analysis. Mycol. Res. 95:1025-1046.

44. Peters, R. D., Förster, H., Platt, H. W., Hall, R., and Coffey, M. D. 2001. Novel genotypes of Phytophthora infestans in Canada during 1994 and 1995. Am. J. Potato Res. 78:39-45.

45. Peters, R. D., Platt, H. W., and Hall, R. 1998. Changes in race structure of Canadian populations of Phytophthora infestans based on specific virulence to selected potato clones. Potato Res. 41:355-370.

46. Peters R. D., Platt H. W., and Hall R. 1998. Characterization of changes in populations of Phytophthora infestans in Canada using mating type and metalaxyl sensitivity markers. Can. J. Plant Pathol. 20:259-273.

47. Peters, R.D., Platt, H. W., and Hall, R. 1999. Hypotheses for the inter-regional movement of new genotypes of Phytophthora infestans in Canada. Can. J. Plant Pathol. 21:132-136.

48. Peters, R. D., Platt, H. W., and Hall, R. 1999. Use of allozyme markers to determine genotypes of Phytophthora infestans in Canada. Can. J. Plant Pathol. 21:144-153

49. Peters, R. D., Platt, H. W., Hall, R., and Medina, M. 1999. Variation in aggressiveness of Canadian isolates of Phytophthora infestans as indicated by their relative abilities to cause potato tuber rot. Plant Dis. 83:652-661.

50. Platt, H. W., Peters, R. D., Medina, M., and Arsenault, W. 1999. Impact of seed potatoes infected with Phytophthora infestans (US-1 or US-8 genotypes) on crop growth and disease risk. Am. J. Potato Res. 75:67-73.

51. Shattock, R. C., and Day, J. P. 1996. Migration and displacement; recombinants and relicts: 20 years in the life of potato late-blight (Phytophthora infestans). Pages 1129-1136 in: Proc. Brighton Crop Prot. Conf. Pests Dis. British Crop Protection Council, Farnham, Surrey, UK.

52. Spielman, L. J., Drenth, A., Davidse, L. C., Sujkowski, L. J., Gu, W. K., Tooley, P. W., and Fry, W. E. 1991. A second world-wide migration and population displacement of Phytophthora infestans? Plant Pathol. 40:422430 .

53. Sujkowski, L. S., Goodwin, S. B., Dyer, A. T., and Fry, W. E. 1994. Increased genotypic diversity via migration and possible occurrence of sexual reproduction of Phytophthora infestans in Poland. Phytopathology 84:201207.

54. Vartanian, V. G., and Endo, R. M. 1985. Overwintering hosts, compatibility types, and races of Phytophthora infestans on tomato in southern California. Plant Dis. 69:516-519. 